\title{
OSMO-, THERMO- AND ETHANOL- TOLERANCES OF SACCHAROMYCES CEREVISIAE , $_{1}$
}

\author{
Sandrasegarampillai Balakumar, Vasanthy Arasaratnam*
}

Department of Biochemistry, Faculty of Medicine, University of Jaffna, Kokuvil, Sri Lanka.

Submitted: August 16, 2010; Returned to authors for corrections: April 27, 2011; Approved: January 16, 2012.

\begin{abstract}
Saccharomyces cerevisiae $\mathrm{S}_{1}$, which is a locally isolated and improved strain showed viability at 40,45 and $50^{\circ} \mathrm{C}$ and produced ethanol at 40,43 and $45^{\circ} \mathrm{C}$. When the cells were given heat shock at $45^{\circ} \mathrm{C}$ for $30 \mathrm{~min}$ and grown at $40^{\circ} \mathrm{C}, 100 \%$ viability was observed for $60 \mathrm{~h}$, and addition of $200 \mathrm{gL}^{-1}$ ethanol has led to complete cell death at $30 \mathrm{~h}$. Heat shock given at $45^{\circ} \mathrm{C}$ (for $30 \mathrm{~min}$ ) has improved the tolerance to temperature induced ethanol shock leading to $37 \%$ viability at $30 \mathrm{~h}$. When the cells were subjected to ethanol $\left(200 \mathrm{gL}^{-1}\right.$ for 30 min) and osmotic shock (sorbitol $300 \mathrm{gL}^{-1}$ ), trehalose contents in the cells were increased. The heat shocked cells showed better viability in presence of added ethanol. Soy flour supplementation has improved the viability of $S$. cerevisiae $\mathrm{S}_{1}$ to $80 \%$ in presence of $100 \mathrm{gL}^{-1}$ added ethanol and to $60 \%$ in presence of $300 \mathrm{gL}^{-1}$ sorbitol. In presence of sorbitol $\left(200 \mathrm{gL}^{-1}\right)$ and ethanol $\left(50 \mathrm{gL}^{-1}\right)$ at $40^{\circ} \mathrm{C}, 46 \%$ viability was retained by $S$. cerevisiae $\mathrm{S}_{1}$ at $48 \mathrm{~h}$ and it was improved to $80 \%$ by soy flour supplementation.
\end{abstract}

Key words: Thermo-tolerance, ethanol-tolerance, osmo-tolerance, viability Saccharomyces cerevisiae

\section{INTRODUCTION}

The tolerance of yeast to its substrate (osmo-tolerance), fermentation product (ethanol- tolerance) and temperature (thermo-tolerance) has great potential to be used in industrial scale fermentation. At the beginning of fermentation, cells are subjected to high substrate concentration and as the ethanol level increases, both the substrate and product causes stress to the organism (14). During fermentation, heat is liberated due to exothermic reactions and if the environmental temperature is already high, the fermenter temperature tends to increase (1). Therefore the yeast should have temperature-, osmotic pressure- and ethanol- tolerating capacities to perform efficiently in industrial scale. In tropical countries like Sri Lanka, maintaining the operating temperature at or around the optimum fermentation temperature requires cooling, which is expensive. Significant cost savings become apparent if the fermenter can be kept at or above $40^{\circ} \mathrm{C}$. In addition, ethanol recovery cost shall also be low if the process is carried out at higher temperatures. This however would require a yeast strain that could produce high titre of ethanol at higher temperatures.

Good yeast strain should have osmo-, ethanol- and combined ethanol and osmo-tolerances along with thermotolerance properties. Therefore this study was undertaken to evaluate the tolerance levels and fermentative capacities of a locally isolated and improved organism, Saccharomyces

*Corresponding Author. Mailing address: Department of Biochemistry, Faculty of Medicine, University of Jaffna, Kokuvil, Sri Lanka.; Tel.: 009421222 6514.; E-mail: arva26arva@yahoo.com 
cerevisiae $\mathrm{S}_{1}$ (2) up to $45^{\circ} \mathrm{C}$ for its application in local distilleries.

\section{MATERIALS AND METHODS}

\section{Materials}

Soy bean from local market was powdered and dried at $80^{\circ} \mathrm{C}$. All the other materials were purchased from standard suppliers: culture media Oxoid limited USA, and other chemicals are from Sigma-Aldrich, USA.

\section{Saccharomyces cerevisiae $\mathrm{S}_{1}$}

Saccharomyces cerevisiae $\mathrm{S}_{1}$ is a locally isolated and improved thermotolerant strain (2); maintained in peptone, yeast extract and nutrient $(\mathrm{PYN})-\operatorname{agar}\left(2.5 \mathrm{gL}^{-1}\right)$ slants.

\section{Analytical methods}

Glucose (23), trehalose (TCA soluble anthrone positive carbohydrate) (36), ethanol (39) and viable cell count (30) were determined by standard methods.

\section{Peptone, yeast extract and nutrient (PYN) medium}

The medium contained $\left(\mathrm{gL}^{-1}\right)$ peptone, 3.5, yeast extract, 3.0, $\mathrm{MgSO}_{4} .7 \mathrm{H}_{2} \mathrm{O}, 1.0, \mathrm{KH}_{2} \mathrm{PO}_{4}, 2.0$; and $\left(\mathrm{NH}_{4}\right)_{2} \mathrm{SO}_{4}, 1.0$ at $\mathrm{pH}$ 5.0. Under different experimental conditions, different amounts of glucose were added to the medium and represented as glucose (amount in $\mathrm{gL}^{-1}$ ) - PYN medium (2).

\section{Inoculum of $S$. cerevisiae $S_{1}$}

Glucose $\left(50 \mathrm{gL}^{-1}\right)-$ PYN medium $(100 \mathrm{~mL})$ was inoculated with 2 loops full of Saccharomyces cerevisiae $\mathrm{S}_{1}$ and incubated at $36^{\circ} \mathrm{C}$ for $18 \mathrm{~h}$ with shaking at $150 \mathrm{rpm}$.

\section{Thermo- tolerance and ethanol production}

S. cerevisiae $\mathrm{S}_{1}$ grown at $36^{\circ} \mathrm{C}$ in glucose $\left(50 \mathrm{gL}^{-1}\right)-\mathrm{PYN}$ medium for $18 \mathrm{~h}$ was incubated at $40,45,50$ and $55^{\circ} \mathrm{C}$ separately in triplicates and viability was monitored. All the following treatments were done in triplicates. For the ethanol production studies, inocua $(10 \%, \mathrm{v} / \mathrm{v}, 18 \mathrm{~h})$ were added to the glucose $\left(100 \mathrm{gL}^{-1}\right)$ - PYN medium and incubated at 40, 43 and $45^{\circ} \mathrm{C}$ separately with shaking (150rpm).

\section{Temperature shift cultivation on ethanol -tolerance}

Culture of $S$. cerevisiae $\mathrm{S}_{1}$ prepared at $36^{\circ} \mathrm{C}$ in glucose $\left(50 \mathrm{gL}^{-1}\right)$ - PYN medium was given different treatments as shown in Table 1 and the viable cell count was monitored.

Table 1. S. cerevisiae $\mathrm{S}_{1}$ culture grown at $36^{\circ} \mathrm{C}$ in glucose $\left(50 \mathrm{gL}^{-1}\right)$ - PYN medium were given different treatments. After the different treatment the cultures were incubated at the indicated temperature.

\begin{tabular}{|c|c|c|c|}
\hline \multirow{2}{*}{$\begin{array}{c}\text { Culture } \\
\text { No. }\end{array}$} & \multicolumn{2}{|c|}{ Treatment } & \multirow{2}{*}{$\begin{array}{c}\text { "Incubation } \\
\text { Temperature } \\
\left({ }^{\mathrm{O}} \mathrm{C}\right)\end{array}$} \\
\hline & Heat shock & $\begin{array}{l}\text { Added ethanol } \\
\left(\mathrm{gL}^{-1}\right)\end{array}$ & \\
\hline 1 & - & - & 36 \\
\hline 2 & - & 200 & 36 \\
\hline 3 & - & - & 40 \\
\hline 4 & - & 200 & 40 \\
\hline 5 & $45^{\circ} \mathrm{C}$ for $30 \mathrm{~min}$ & - & 40 \\
\hline 6 & $45^{\circ} \mathrm{C}$ for $30 \mathrm{~min}$ & 200 & 40 \\
\hline
\end{tabular}

\section{Heat shock on trehalase content and thermo-tolerance}

To $18 \mathrm{~h}$ old $S$. cerevisiae $\mathrm{S}_{1}$ grown at $36^{\circ} \mathrm{C}$ in glucose $\left(50 \mathrm{gL}^{-1}\right)$ - PYN medium, heat shock was given by incubating at $45^{\circ} \mathrm{C}$ for $30 \mathrm{~min}$. Control did not have heat treatment. Then $1 \mathrm{~mL}$ aliquots of the test and control cultures were mixed with $1 \mathrm{~mL}$ normal saline (pre-equilibrated at $58^{\circ} \mathrm{C}$ ) and incubated at $58^{\circ} \mathrm{C}$ for $5 \mathrm{~min}$. The viability was determined. Trehalose was extracted (37) and estimated (36). Yeast cells without heat shock were used as control. Weight of the dry cells was measured.

\section{Ethanol shock on trehalose content}

Ethanol content in the $S$. cerevisiae $\mathrm{S}_{1}$ culture grown for $18 \mathrm{~h}$ at $36^{\circ} \mathrm{C}$ in glucose $\left(50 \mathrm{gL}^{-1}\right)-\mathrm{PYN}$ medium was measured and ethanol was added to make up the total concentration to $200 \mathrm{gL}^{-1}$. After $30 \mathrm{~min}$, cells subjected to ethanol shock were harvested by centrifugation $\left(7 \times 10^{3} \mathrm{rpm}\right)$ and trehalose content and dry cell weight were measured. To the control, no ethanol shock was given. 


\section{Growth temperature on thermo-tolerance}

$S$. cerevisiae $\mathrm{S}_{1}$ inocula prepared at 28,32 and $36^{\circ} \mathrm{C}$ were incubated at $58^{\circ} \mathrm{C}$ and viability was monitored. In another setup 18 old culture grown at $28^{\circ} \mathrm{C}$ was incubated at $36^{\circ} \mathrm{C}$ for 90 min and then incubated at $58^{\circ} \mathrm{C}$ and the viability was monitored.

\section{Soy flour supplementation on thermo-tolerance}

Viability of $S$. cerevisiae $\mathrm{S}_{1}$ grown at $40^{\circ} \mathrm{C}$ in glucose $\left(100 \mathrm{gL}^{-1}\right)$ - PYN medium supplemented with $20 \mathrm{gL}^{-1}$ soy flour was monitored while the control medium did not have soy flour.

\section{Soy flour supplementation on osmo-tolerance}

Sorbitol $\left(0-400 \mathrm{gL}^{-1}\right)$ was added to glucose $\left(100 \mathrm{gL}^{-1}\right)-$ PYN. Soy flour $\left(40 \mathrm{gL}^{-1}\right)$ was added to the test while the control did not have soy flour. Glucose $\left(200 \mathrm{gL}^{-1}\right)-\mathrm{PYN}$ medium and glucose $\left(300 \mathrm{gL}^{-1}\right)-\mathrm{PYN}$ medium with and without soy flour supplementation were also taken. Viable cell count and ethanol were determined at $48 \mathrm{~h}$ of incubation.

\section{Soy flour supplementation on ethanol tolerance}

To glucose $\left(100 \mathrm{gL}^{-1}\right)$ - PYN medium with and without soy flour $\left(40 \mathrm{gL}^{-1}\right)$, ethanol $\left(0-200 \mathrm{~g} \mathrm{~L}^{-1}\right)$ was added and incubated at $40^{\circ} \mathrm{C}$. Viable cell count and ethanol were measured at $48 \mathrm{~h}$.

\section{Combined effects of osmo- and ethanol - stresses}

Sorbitol $\left(200 \mathrm{gL}^{-1}\right)$ was added separately into different medium prepared with and without soy flour and, viable cell count and ethanol were measured at $48 \mathrm{~h}$.

\section{RESULTS AND DISCUSSION}

\section{Thermo-tolerance and ethanol production}

When $18 \mathrm{~h}$ old cultures of $S$. cerevisiae $\mathrm{S}_{1}$ grown in glucose $\left(50 \mathrm{gL}^{-1}\right)-\mathrm{PYN}$ at $36^{\circ} \mathrm{C}$ were incubated at different temperatures, the organism retained $100 \%$ viability up to 72 , $10.0,2.0$ and $0.5 \mathrm{~h}$ respectively at $40,45,50$ and $55^{\circ} \mathrm{C}$ and the organism lost $50 \%$ of its viability at $120,66,39$ and $5 \mathrm{~h}$ at the respective temperatures (Figure 1). Since the organism showed considerable viability at higher temperatures, its ethanol producing ability at 40,43 and $45^{\circ} \mathrm{C}$ were studied. Temperatures above $45^{\circ} \mathrm{C}$ were not considered, as the fermentation processes do not exceed $42^{\circ} \mathrm{C}$ in large industrial level operations (1). The ethanol production at 40, 43 and $45^{\circ} \mathrm{C}$ in glucose $\left(100 \mathrm{gL}^{-1}\right)-\mathrm{PYN}$ medium was 46,38 and $26 \mathrm{gL}^{-1}$ respectively (Table 2 ). D'Amore et al., (7) also have shown that the increase in the temperature from 40 to $45^{\circ} \mathrm{C}$ resulted in a decrease in the rate and extent of glucose utilization and ethanol production. Since $S$. cerevisiae $\mathrm{S}_{1}$ was able to survive and produce ethanol from 40 to $45^{\circ} \mathrm{C}$, the effect of heat stress on its ethanol tolerance was studied.

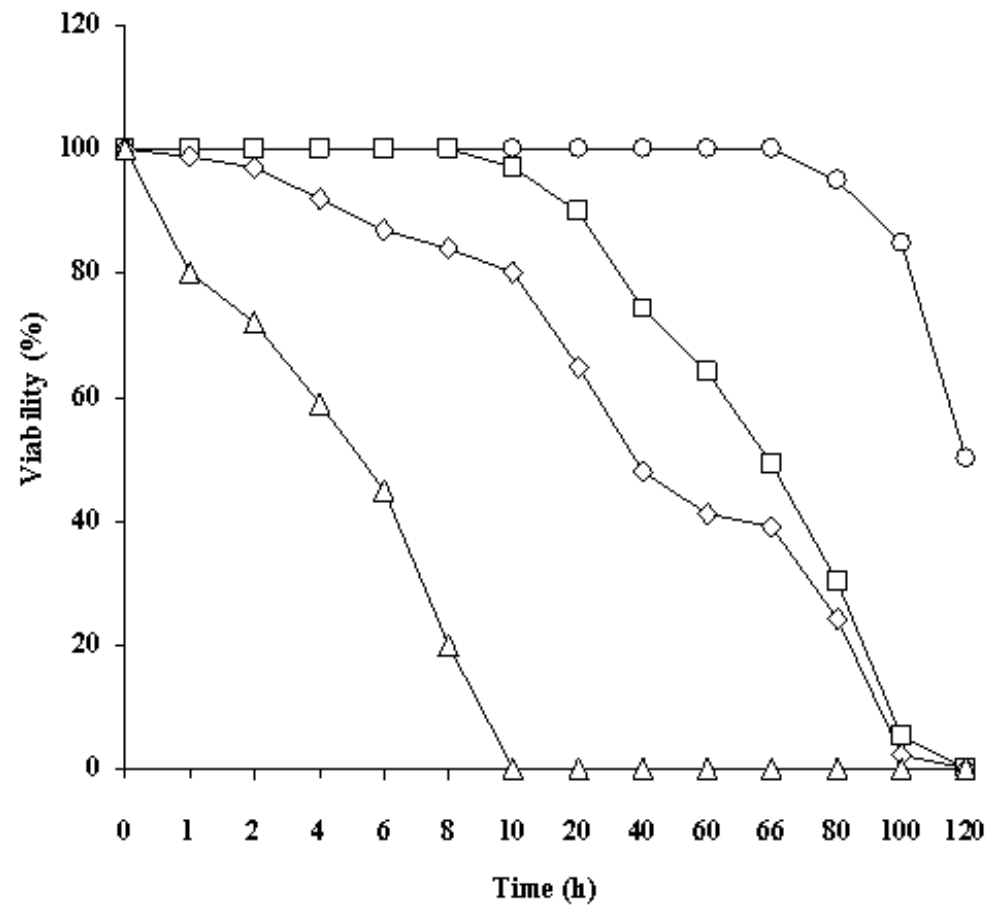

Figure 1. Viability of $S$. cerevisiae $S_{1}$ grown in glucose $\left(50 \mathrm{gL}^{1}\right)-\mathrm{PYN}$ medium at $36^{\circ} \mathrm{C}$ and the $18 \mathrm{~h}$ old culture was subjected to heat treatment at $(\circ) 40 ;(\square) 45 ;(\diamond) 50$ and $(\triangle)$ $55^{\circ} \mathrm{C}$. 
Table 2. Ethanol production by $S$. cerevisiae $\mathrm{S}_{1}$ at different temperatures in glucose $\left(100 \mathrm{gL}^{-1}\right)$ - PYN medium at $24 \mathrm{~h}$.

\begin{tabular}{ccccc}
\hline $\begin{array}{c}\text { Temperature } \\
\left({ }^{\mathbf{0}} \mathbf{C}\right)\end{array}$ & $\begin{array}{c}\text { Ethanol } \\
\left(\mathbf{g L}^{-\mathbf{1}}\right)\end{array}$ & $\begin{array}{c}\text { Residual sugar } \\
\left(\mathbf{g L} \mathbf{-}^{-\mathbf{1}}\right)\end{array}$ & $\begin{array}{c}\text { Ethanol production efficiency } \\
\mathbf{( \% )}\end{array}$ & $\begin{array}{c}\text { Sugar utilization } \\
\mathbf{( \% )}\end{array}$ \\
\hline 40 & 46 & 0.0 & 91.0 & 100.0 \\
43 & 38 & 19.5 & 74.4 & 80.5 \\
45 & 26 & 45.0 & 50.8 & 55.0 \\
\hline Ethanol production efficiency = Ethanol produced/ Theoretical maximum of ethanol that could be produced from initial glucose.
\end{tabular}

\section{Temperature shift cultivation on ethanol - tolerance}

When 18 h old $S$. cerevisiae $\mathrm{S}_{1}$ inoculum was given different treatments (Table 1) and grown at either 36 or $40^{\circ} \mathrm{C}$, the viability of control cultures which had no treatments (heat shock or added ethanol) at either 36 or $40^{\circ} \mathrm{C}$ remained almost $100 \%$ (Figure 2). The heat shocked cells (at $45^{\circ} \mathrm{C}$ for $30 \mathrm{~min}$ ) showed $100 \%$ viability when they were grown at $40^{\circ} \mathrm{C}$ without added ethanol. When $200 \mathrm{gL}^{-1}$ ethanol was added to the culture (18h) grown at $36^{\circ} \mathrm{C}$, complete death of cells was observed at $60 \mathrm{~h}$, whereas at $40^{\circ} \mathrm{C}$ in presence of ethanol complete cell death occurred at $30 \mathrm{~h}$. Therefore the toxic effect of ethanol was aggravated by the increase in incubation temperature. However the temperature induced ethanol toxicity was nullified by a brief heat shock (30min) at $45^{\circ} \mathrm{C}$. Heat shocked culture showed $37 \%$ viability at 30 $\mathrm{h}$ at $40^{\circ} \mathrm{C}$ in the presence of ethanol as against complete cell death of the cells, which were not given heat shock.

It was reported that ethanol had specific and non-specific effects directly on membranes and proteins (16). Heat shock leads to changes in the fatty acid composition of the membranes (22, $25)$, synthesis of heat shock proteins $(5,12,17,22,40)$ and accumulation of trehalose $(19,38,4,11,15,26,28,29,31,32,33$, 42). To evaluate whether the heat shock induced ethanol tolerance in Saccharomyces cerevisiae $\mathrm{S}_{1}$ was due to the accumulation of trehalose (TCA soluble anthrone positive carbohydrate), the changes in trehalose content along with heat shock and thermotolerance were studied.

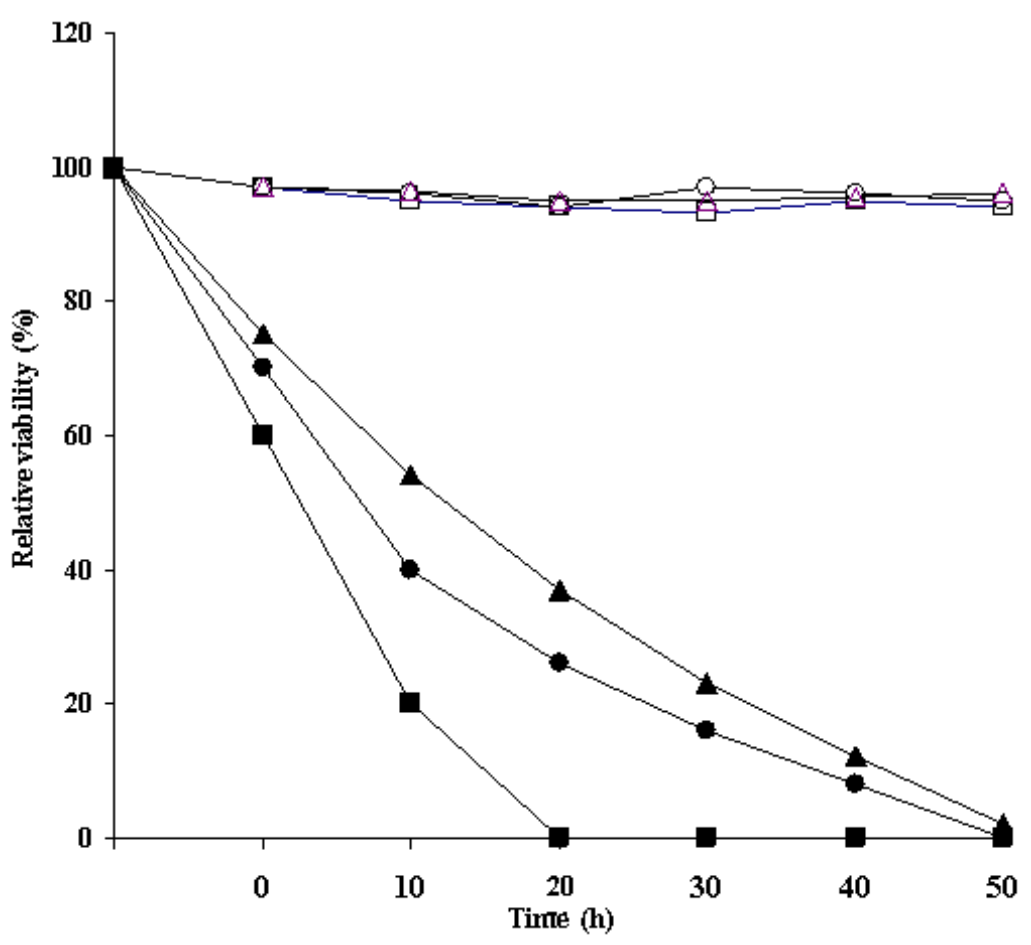

Figure 2. Effect of heat shock on ethanol tolerance of $S$. cerevisiae $\mathrm{S}_{1}$. Inoculum was developed at $36^{\circ} \mathrm{C}$ and to the $18 \mathrm{~h}$ old culture ethanol $\left(200 \mathrm{gL}^{-1}\right)$ was added. Viability at (O) $36^{\circ} \mathrm{C}$ without ethanol; (O) $36^{\circ} \mathrm{C}$ with ethanol; ( $\square) \quad 40^{\circ} \mathrm{C}$ without ethanol; (ם) $40^{\circ} \mathrm{C}$ with ethanol $(\triangle)$ at $40^{\circ} \mathrm{C}$ without ethanol after heat shock and $(\Delta)$ at $40^{\circ} \mathrm{C}$ with ethanol after heat shock. 


\section{Heat shock on trehalose content and thermo-tolerance}

Trehalose content was increased by $90.3 \%$ in heat shocked cells; while $28 \%$ viability was observed at $30 \mathrm{~h}$ for heat shocked cells as against complete cell death for culture not undergone heat shock. Trehalose content was increased from $62( \pm 2.0)$ to $118( \pm 5.0) \quad(\mu$ mole glc / g dry cell weight) after heat shock treatment. Therefore the increase in trehalose content could be linked to enhanced thermo- tolerance of $S$. cerevisiae $\mathrm{S}_{1}$ cells as for other yeast $(19,28,34)$ strains. Accumulation of enormous amounts of trehalose (28) could be due to increased levels of trehalose metabolism (42). Trehalose at first regarded only as an energy reserve (13), but latter studies have shown the correlation between the trehalose content of yeast cells and their resistance to temperature extremes $(24,28,41)$, high osmotic pressure and high ethanol concentrations (18). Trehalose acts as a protecting agent to the cell membranes and proteins under conditions that deplete intracellular water $(6,9)$. Since the relationship between trehalose content and thermotolerance was observed in this study, the effect of ethanol stress on the trehalose content of the cells was also studied.

\section{Ethanol shock on trehalose content}

Trehalose content was $66( \pm 1.0)$ and $95( \pm 4.0) \mu$ moles glucose equivalent/dry cell weight respectively in control and test samples. A $44 \%$ increase in trehalose content was induced by ethanol shock. Ethanol causes water stress by lowering water activity $\left(\mathrm{a}_{\mathrm{w}}\right)$ and thereby interferes with hydrogen bonding within and between hydrated cell components leading to ultimate disruption of enzymes and membrane structure and function (8). Yeast cells exposed to ethanol, synthesize compatible solutes such as glycerol and trehalose as protectants (14). Ethanol induced leakage was inhibited by the accumulated trehalose $(20,26,27)$. Under water stress, cells synthesize compounds that protect the structure and function of hydrated cell components, the compatible solutes and the trehalose formed show protective effects on membranes (28). When the ethanol shock as well as heat shock was studies individually, both studies have shown the induced accumulation of trehalose. In the mean time heat shocked cells showed better ethanol tolerance. The stress conditions have been circumvented by the production of trehalose. The accumulation of trehalose in the heat shocked cells was more than that in the ethanol stressed cells. Since the heat shock at $45^{\circ} \mathrm{C}$ for $30 \mathrm{~min}$ has improved the viability of $S$. cerevisiae $\mathrm{S}_{1}$, the effect of growth temperature on the thermo-tolerance of the organism was studied.

\section{Growth temperature on thermo-tolerance}

The cultures grown at different temperatures showed vast difference in thermo-tolerance at $58^{\circ} \mathrm{C}$ (Figure 3). In addition to growth temperature, heat shock prior to high temperature exposure had significant effect on thermo-tolerance. When the culture grown at $28^{\circ} \mathrm{C}$ were incubated at $36^{\circ} \mathrm{C}$ and was subjected to $58^{\circ} \mathrm{C}, 20 \%$ viability was observed, while the cells directly transferred from 36 to $58^{\circ} \mathrm{C}$ showed $2 \%$ viability at $10 \mathrm{~h}$.

The increase in the thermo-tolerance due to the rapid shift in growth temperature from 28 to $36^{\circ} \mathrm{C}$ resulted in protection from death at $58^{\circ} \mathrm{C}$. When the growth temperatures were 23 , 30 and $36^{\circ} \mathrm{C}$, the survival fraction $(\%)$ of the S. cerevisiae at $52^{\circ} \mathrm{C}$ at $5 \mathrm{~min}$ were 90,10 and 0.8 respectively (7). In our experiment the cultures grown at 28,32 and $36^{\circ} \mathrm{C}$ showed 1,12 and $28 \%$ viability at $58^{\circ} \mathrm{C}$ after $5 \mathrm{~h}$. The shift in growth temperature from 28 to $36^{\circ} \mathrm{C}$ has resulted in significant increase in viability $(50 \%)$. Viability of the cells at $58^{\circ} \mathrm{C}$ reached zero at 10 and $20 \mathrm{~h}$ with cultures grown at 28 and $32^{\circ} \mathrm{C}$ respectively. At 30min, 0.1 and $1.0 \%$ viability was observed with cultures grown at $36^{\circ} \mathrm{C}$ and heat shocked $\left(28\right.$ to $\left.36^{\circ} \mathrm{C}\right)$ cultures respectively. Shifting yeast culture from 23 to $36^{\circ} \mathrm{C}$ for a brief period would result in improved viability (22). 


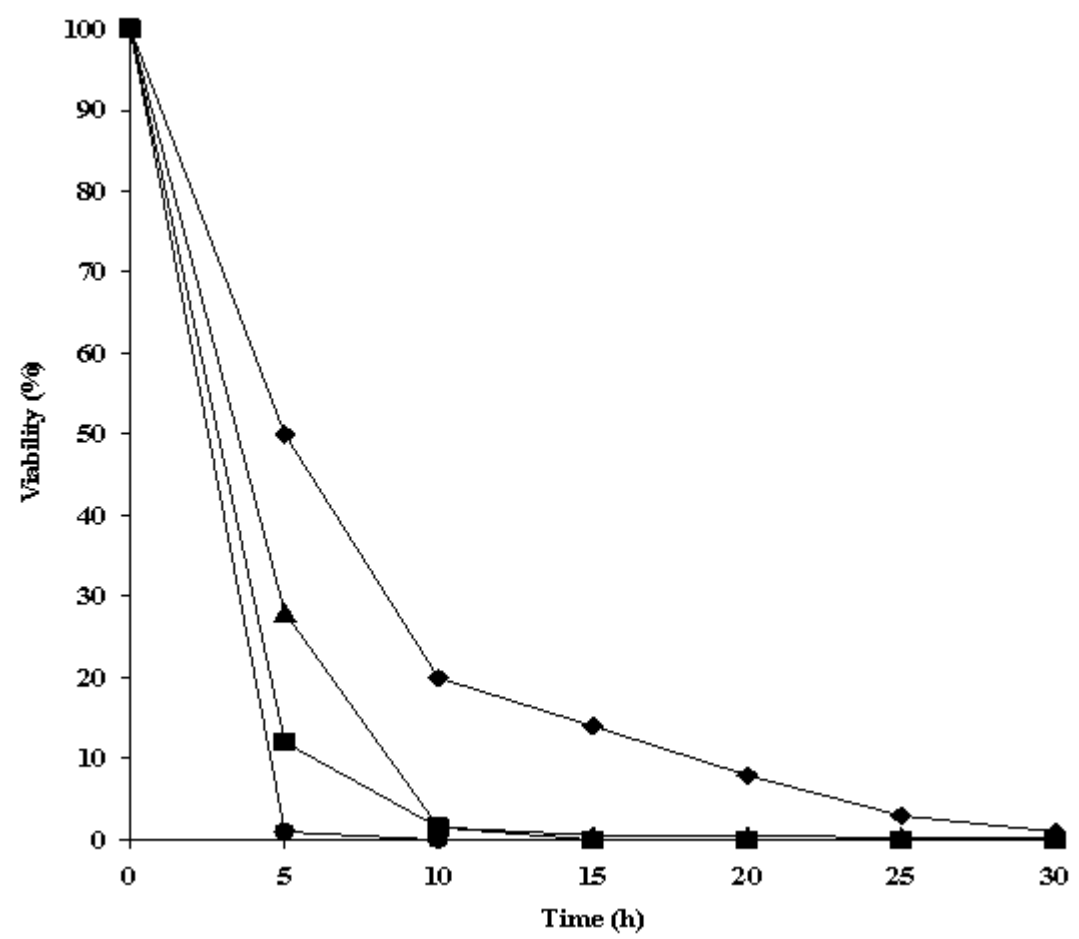

Figure 3. Viability of $S$. cerevisiae $\mathrm{S}_{1}$ at $40^{\circ} \mathrm{C}$ after the heat shock at $58^{\circ} \mathrm{C}$. The cells grown at $(\bullet) 28$; (๘) 32 and $(\boldsymbol{\Delta})$ $36^{\circ} \mathrm{C}$, and $(\diamond)$ grown at $28^{\circ} \mathrm{C}$ incubated at $36^{\circ} \mathrm{C}$ for $90 \mathrm{~min}$, prior to heat shock at $58^{\circ} \mathrm{C}$.

\section{Soy flour supplementation on thermo-tolerance}

Soy flour supplementation has improved the thermotolerance of $S$. cerevisiae $S_{1}$ at high temperature (Table 3). At $40^{\circ} \mathrm{C}$, when soy flour was supplemented, the duration of $100 \%$ viability was extended from 72 to $86 \mathrm{~h}$. At $45^{\circ} \mathrm{C}$ the same was increased from 10 to $16 \mathrm{~h}$ by soy flour supplementation. The soy flour supplement was not effective at 50 and $55^{\circ} \mathrm{C}$. The increase in the viability at 40 and $45^{\circ} \mathrm{C}$ by soy flour supplementation suggests that $S$. cerevisiae $\mathrm{S}_{1}$ cells required additional nutrients to withstand high temperature. Addition of $1 \%$ yeast extract and $1 \mu \mathrm{mol}$ oleic acid $\left(\mathrm{mL} \mathrm{medium}^{-1}\right)$ has eliminated the initial death phase of $S$. cerevisiae at $40^{\circ} \mathrm{C}(42)$. Soybean flour contains $38 \%$ proteins and $21 \%$ lipids (44), and of the lipids appreciable amount (26\%) of oleic acid is present (3). Therefore the effect of soy flour could be linked to its oleic acid content. Beneficial effects of soybean on viability of cells in high gravity molasses at high temperature was reported (10). One effect of heat is to induce nutritional requirements for lipids (44). Therefore improvement in thermo-tolerance by soy flour supplementation could be due to its unsaturated fatty acid content. Since soy flour has improved the thermo-tolerance of S. cerevisiae $\mathrm{S}_{1}$, its effect on osmo- tolerance was determined.

Table 3. Viability of $S$. cerevisiae $S_{1}$ at different temperatures. The indicated times represent the maximum period to which the strain was able to retain $100 \%$ viability.

\begin{tabular}{lllll}
\hline Medium & \multicolumn{4}{c}{ Time (h) } \\
\cline { 2 - 5 } & $\mathbf{4 0}^{\mathbf{0}} \mathbf{C}$ & $\mathbf{4 5}^{\mathbf{0}} \mathbf{C}$ & $\mathbf{5 0}^{\mathbf{0}} \mathbf{C}$ & $\mathbf{5 5}^{\mathbf{0}} \mathbf{C}$ \\
\hline Glucose $\left(100 \mathrm{gL}^{-1}\right)-\mathrm{PYN}$ & 72 & 10.0 & 2.0 & 0.5 \\
Glucose $\left(100 \mathrm{gL}^{-1}\right)-\mathrm{PYN}+$ Soy flour $\left(20 \mathrm{gL}^{-1}\right)$ & 86 & 16 & 3.0 & 1.0 \\
\hline
\end{tabular}




\section{Soy flour supplementation on osmo-tolerance}

The osmo-tolerance of $S$. cerevisiae $\mathrm{S}_{1}$ in presence of different concentrations of $\left(0-400 \mathrm{gL}^{-1}\right)$ of non-metabolizable sugar sorbitol (44) was determined.

The viability and ethanol producing ability of $S$. cerevisiae $\mathrm{S}_{1}$ were significantly not affected by sorbitol up to $100 \mathrm{gL}^{-1}$. With $200 \mathrm{gL}^{-1}$ sorbitol (containing $100 \mathrm{gL}^{-1}$ glucose), the viability and the ethanol production were reduced to $60 \%$ and $30 \mathrm{gL}^{-1}$ respectively (Table 4). Further increase in sorbitol exerted severe effect on both viability and ethanol production. Therefore the results suggest that high sugar levels caused the death of the cells along with decreasing ethanol producing ability, i.e. both the aerobic and anaerobic metabolisms of the yeast were affected. Increase in solute concentration results in increased osmotic pressure and decreased water activity (14, 44). It has been previously reported that the increase in the osmotic pressure of the medium can decrease the viability and fermentative ability, in addition to the intracellular ethanol (44).

Supplementation of soy flour increased the viability and fermentative ability of $S$. cerevisiae $\mathrm{S}_{1}$ at high sugar levels (Table 4). Therefore the additional nutrients support $S$. cerevisiae $\mathrm{S}_{1}$ to combat the osmotic pressure and / or water stress.

The sugar utilization and ethanol production efficiency of S. cerevisiae $\mathrm{S}_{1}$ are higher in sorbitol $\left(100 \mathrm{gL}^{-1}\right)$ - glucose $\left(100 \mathrm{gL}^{-1}\right)$ - PYN medium than glucose $\left(200 \mathrm{gL}^{-1}\right)-\mathrm{PYN}$ (without sorbitol) (Table 5). However, when these media were supplemented with soy flour, increased sugar utilization and ethanol production efficiency were observed with glucose $\left(200 \mathrm{gL}^{-1}\right)$ - PYN (without sorbitol) medium. The same is true when either $200 \mathrm{gL}^{-1}$ sorbitol or $200 \mathrm{gL}^{-1}$ glucose was added to glucose $\left(100 \mathrm{gL}^{-1}\right)$ - PYN medium (Table 4). From the results it can be concluded that the inhibitory effect given by metabolizable sugar was more than that of non-metabolizable sugar and this effect could be rectified by adding soy flour $\left(40.0 \mathrm{gL}^{-1}\right)$ to PYN medium. The studies showed that both viability and ethanol fermentative ability of $S$. cerevisiae $\mathrm{S}_{1}$ were affected by increasing the osmotic pressure and these effects were reduced by the soy flour supplementation. A study was carried out to find the tolerance property of the organism to both osmotic and ethanol stresses in presence of soy flour.

Table 4. The effect of soy flour $\left(40 \mathrm{gL}^{-1}\right)$ supplementation on osmo-tolerance, ethanol production, ethanol production efficiency (EPE) and sugar utilization under different conditions by S. cerevisiae $\mathrm{S}_{1}$ cells in glucose (100 or $200 \mathrm{or}^{300 \mathrm{gL}} \mathrm{L}^{-1}$ ) $\mathrm{PYN}$ medium at $48 \mathrm{~h}$ and $40^{\circ} \mathrm{C}$.

\begin{tabular}{|c|c|c|c|c|c|c|c|c|c|}
\hline \multirow{2}{*}{$\begin{array}{c}\text { Glucose } \\
\left(\mathrm{gL}^{-1}\right)\end{array}$} & \multirow{2}{*}{$\begin{array}{c}\text { Sorbitol } \\
\left(\mathbf{g L}^{-1}\right)\end{array}$} & \multicolumn{4}{|c|}{ PYN } & \multicolumn{4}{|c|}{ PYN + Soy flour } \\
\hline & & $\begin{array}{c}\text { Viability } \\
(\%)\end{array}$ & $\begin{array}{c}\text { Ethanol } \\
\left(\mathrm{gL}^{-1}\right)\end{array}$ & $\begin{array}{c}\text { Sugar } \\
\text { utilization } \\
(\%)\end{array}$ & $\begin{array}{l}\text { EPE } \\
(\%)\end{array}$ & $\begin{array}{c}\text { Viability } \\
(\%)\end{array}$ & $\begin{array}{c}\text { Ethanol } \\
\left(\mathrm{gL}^{-1}\right)\end{array}$ & $\begin{array}{c}\text { Sugar } \\
\text { utilization } \\
(\%)\end{array}$ & $\begin{array}{l}\text { EPF } \\
(\%)\end{array}$ \\
\hline 100 & 0 & 96 & 46 & 100 & 90.0 & 97 & 47.0 & 100.0 & 92.0 \\
\hline 100 & 50 & 95 & 45 & 100 & 88.0 & 97 & 47.0 & 100.0 & 92.0 \\
\hline 100 & 100 & 90 & 42 & 90 & 82.0 & 97 & 46.0 & 97.0 & 90.0 \\
\hline 100 & 200 & 60 & 30 & 62 & 58.7 & 90 & 43.0 & 90.0 & 84.0 \\
\hline 100 & 300 & 38 & 20 & 57 & 39.0 & 60 & 32.0 & 67.8 & 62.6 \\
\hline 100 & 400 & 5 & 8 & 83 & 15.6 & 25 & 19.0 & 40.2 & 37.0 \\
\hline 200 & - & ND & 75 & 79 & 73.3 & ND & 98.6 & 100.0 & 96.5 \\
\hline 300 & - & ND & 82 & 60 & 53.5 & ND & 149 & 100.0 & 97.0 \\
\hline
\end{tabular}

\# Viability $(\%)=($ Viable cells / Total cells $)$ x 100

ND - Not determine 
Table 5. Effect of added ethanol concentration on viability of $S$. cerevisiae $\mathrm{S}_{1}$ and ethanol production in glucose $\left(100 \mathrm{gL}{ }^{-1}\right)-\mathrm{PYN}$ medium and in soy flour $\left(40 \mathrm{gL}^{-1}\right)$ supplemented glucose $\left(100 \mathrm{gL}^{-1}\right)-\mathrm{PYN}$ medium at $40^{\circ} \mathrm{C}$ and at $48 \mathrm{~h}$.

\begin{tabular}{|c|c|c|c|c|c|c|}
\hline \multirow{2}{*}{$\begin{array}{c}\text { Ethanol added } \\
\left(\mathrm{gL}^{-1}\right)\end{array}$} & \multicolumn{3}{|c|}{ PYN } & \multicolumn{3}{|c|}{ PYN + Soy flour } \\
\hline & $\begin{array}{c}\text { Viability } \\
(\%)\end{array}$ & $\begin{array}{l}\text { Final ethanol } \\
\left(\mathrm{gL}^{-1}\right)\end{array}$ & $\begin{array}{l}\text { *Ethanol roduced } \\
\left(\mathrm{gL}^{-1}\right)\end{array}$ & $\begin{array}{c}\text { Viability } \\
(\%)\end{array}$ & $\begin{array}{l}\text { Final ethanol } \\
\left(\mathrm{gL}^{-1}\right)\end{array}$ & $\begin{array}{c}\text { *Ethanol produced } \\
\left(\mathrm{gL}^{-1}\right)\end{array}$ \\
\hline 0 & 95 & 46 & 46 & 96 & 48 & 48 \\
\hline 50 & 90 & 90 & 40 & 94 & 92 & 42 \\
\hline 100 & 70 & 128 & 28 & 80 & 132 & 36 \\
\hline 150 & 0 & 155 & 5 & 20 & 172 & 24 \\
\hline 200 & 0 & 200 & 0 & 0 & 204 & 0 \\
\hline
\end{tabular}

\# Viability $(\%)=($ Viable cells / Total cells $) \times 100$

*Ethanol produced $=$ Final ethanol - added ethanol

\section{Soy flour supplementation on ethanol-tolerance}

Ethanol tolerance of $S$. cerevisiae $\mathrm{S}_{1}$ was determined with different concentrations $\left(0-200 \mathrm{gL}^{-1}\right)$ of added ethanol in glucose $\left(100 \mathrm{gL}^{-1}\right)$ - PYN medium supplementation. The effect of soy flour supplementation on ethanol tolerance was also studied. The viability was reduced with the increased added ethanol concentration. Complete cell death was observed at $48 \mathrm{~h}$ with $150 \mathrm{gL}^{-1}$ added ethanol (Table 5). With $100 \mathrm{gL}^{-1}$ added ethanol, the viability was improved from 70 to $80 \%$ with soy flour supplementation at $48 \mathrm{~h}$. With 150 and $200 \mathrm{gL}^{-1}$ added ethanol, complete cell death was observed in un-supplemented media and in soy flour supplemented media 20.0 and $0.0 \%$ viability was observed respectively. The results suggested that soy flour supplementation was ineffective at and above $200 \mathrm{gL}^{-1}$ added ethanol.

Since the soy flour seems to improve the osmo- and ethanol - tolerances individually another experiment was performed to see its effect on combined osmo- and ethanol tolerances of $S$. cerevisiae $\mathrm{S}_{1}$.

\section{Combined effects of osmo- and ethanol - stresses}

Combined effect of different concentrations $\left(0-200 \mathrm{gL}^{-1}\right)$ of added ethanol and sorbitol $\left(200 \mathrm{gL}^{-1}\right)$ on $S$. cerevisiae $\mathrm{S}_{1}$ was studied in glucose $\left(100 \mathrm{gL}^{-1}\right)-\mathrm{PYN}$ and soy flour supplemented glucose $\left(100 \mathrm{gL}^{-1}\right)$ - PYN media separately. With the increase in added ethanol amount to the glucose $\left(100 \mathrm{gL}^{-1}\right)$ - PYN medium having $200 \mathrm{gL}^{-1}$ sorbitol, complete cell death was observed at $100 \mathrm{gL}^{-1}$ added ethanol, while $10 \%$ viability was recorded with the addition of soy flour (Table 6). In the glucose $\left(100 \mathrm{gL}^{-1}\right)$ - PYN medium with $200 \mathrm{gL}^{-1}$ sorbitol, ethanol produced was 28 and $12 \mathrm{gL}^{-1}$ with 0 and $50 \mathrm{gL}^{-1}$ added ethanol respectively (Table 6). Hence the addition of ethanol has reduced ethanol production by $57 \%$. However with soy flour supplementation, the ethanol produced was 42 (without added ethanol) and $30 \mathrm{gL}^{-1}$ (with $50 \mathrm{gL}^{-1}$ added ethanol). This is only a $30 \%$ decrease in ethanol production. Thus soy flour has increased the fermentative ability of the $S$. cerevisiae $\mathrm{S}_{1}$ under combined osmotic- and ethanol - stresses. The viability also has been increased from 60 to 90 and 46 to 80 with soy flour supplementation at 0 and $50 \mathrm{gL}^{-1}$ added ethanol respectively. At higher ethanol levels $\left(100-200 \mathrm{gL}^{-1}\right)$ with sorbitol $\left(200 \mathrm{gL}^{-}\right.$ ${ }^{1}$ ), even the soy flour supplementation could not enhance the viability and fermentative capacity of yeast significantly. The combined effects of osmotic- and ethanol stresses were more pronounced than their individual effects (Table 6). The results suggest that there are additional complex nutritional requirements for the survival of $S$. cerevisiae $S_{1}$ under combined stressed conditions. During high gravity fermentation, initially high osmotic stress is experienced by the strain and as the fermentation proceeds the sugar depletes and the alcohol concentration increases. Hence as the fermentation proceeds, the strain undergoes ethanol stress. Therefore a strain with both ethanol- and osmo- tolerance is necessary to comply with the high gravity fermentation successfully. 
Table 6. Viability of and ethanol produced by $S$. cerevisiae $\mathrm{S}_{1}$ cells in presence and absence of $\left(40 \mathrm{gL}^{-1}\right)$ soy flour with increased concentration of added ethanol while maintaining the sorbitol at $200 \mathrm{gL}^{-1}$ level in glucose $\left(100 \mathrm{gL}^{-1}\right)-\mathrm{PYN}$ media at $40^{\circ} \mathrm{C}$ at $48 \mathrm{~h}$.

\begin{tabular}{|c|c|c|c|c|c|c|c|c|}
\hline \multirow[t]{3}{*}{$\begin{array}{l}\text { Ethanol added } \\
\qquad\left(\mathrm{gL}^{-1}\right)\end{array}$} & \multicolumn{4}{|c|}{$\begin{array}{l}{ }^{\#} \text { Viability } \\
(\%)\end{array}$} & \multicolumn{4}{|c|}{$\begin{array}{c}\text { Ethanol produced by fermentation } \\
\left(\mathrm{gL}^{-1}\right)\end{array}$} \\
\hline & \multicolumn{2}{|c|}{ Without sorbitol } & \multicolumn{2}{|c|}{ With sorbitol } & \multicolumn{2}{|c|}{ Without sorbitol } & \multicolumn{2}{|c|}{ With sorbitol } \\
\hline & PYN & PYN + Soy flour & PYN & PYN + Soy flour & PYN & PYN + Soy flour & PYN & PYN + Soy flour \\
\hline 0 & 95 & 96 & 60 & 90 & 46 & 48 & 28 & 42 \\
\hline 50 & 90 & 94 & 46 & 80 & 40 & 42 & 12 & 30 \\
\hline 100 & 70 & 80 & 0 & 10 & 28 & 32 & 0 & 10 \\
\hline 150 & 0 & 20 & 0 & 5 & 5 & 22 & 0 & 0 \\
\hline 200 & 0 & 0 & 0 & 0 & 0 & 0 & 0 & 0 \\
\hline
\end{tabular}

\#Viability $(\%)=($ Viable cells / Total cells) $\mathrm{x} 100$

\section{CONCLUSION}

S. cerevisiae $\mathrm{S}_{1}$ has shown viability and ethanol producing ability between 40 to $50^{\circ} \mathrm{C}$ and 40 to $45^{\circ} \mathrm{C}$ respectively. When the cells were given heat shock prior to inoculation, they were able to perform better and tolerate heat, ethanol and osmotic stresses by producing trehalose. The cells were able to tolerate thermo-, ethanol and osmotic stresses better in presence of soy flour than in the absence of soy flour. Therefore more detailed study has to be to be made to find the effect of soy flour on $S$. cerevisiae $\mathrm{S}_{1}$.

\section{ACKNOWLEDGEMENTS}

The authors thank the Sida / SAREC and IPICS, Sweden for financial assistance.

\section{REFERENCES}

1. Attfield, P.V.; Raman, A.; Northcott, C.J. (1992). Construction of Saccharomyces cerevisiae strains that accumulate relatively low concentrations of trehalose, and their application in testing the contribution of the disaccharide to stress tolerance. FEMS Microbiol. Lett. 94, 271-276.

2. Balakumar, S.; Arasaratnam, V. (2009). Comparison of industrial scale ethanol production from palmyrah-based carbon source by commercial yeast and a mixed culture from palmyrah toddy. J. Inst. Brew. 115(2), 105-109.

3. Balakumar, S.; Arasaratnam, V.; Balasubramaniam, K. (2001). Isolation and improvement of thermotolerant Saccharomyces cerevisiae strain. World J. Microbiol. Biotechnol. 17(7), 739-746.
4. Budavari, S.; O* Neil, M.J.; Simith, A.; Heckelman, P.E.; Kinneary, J.F. (1996). The Merk Index. $12^{\text {th }}$ Edn, Merk. Research Laboratories. Merk \& Co., Inc. p. 1492 .

5. Canamas, T.P.; Vinas, I.; Usall, J.; Magan, N.; Solsona, C.; Teixido, N. (2008). Impact of mild heat treatments on induction of thermotolerance in the biocontrol yeast Candida sake CPA-1 and viability after spraydrying. J. Appl. Microbiol. 104, 767-775.

6. Cavicchioli, R.; Watson, K. (1986). Loss of heat-shock acquisition of thermotolerance in yeast is not correlated with loss of heat-shock proteins, FEBS Lett. 207(1), 149-152.

7. Crowe, H.J.; Crowe, M.L.; Cahpmann, D. (1984). Preservation of membranes in anhydrobiotic organisms. Science. 223, 701-703.

8. D'Amore, T.; Celotto, G.; Russell, I.; Stewart, G.G. (1989). Selection and optimization of yeast suitable for ethanol production at $40^{\circ} \mathrm{C}$. Enzyme Microbial Technol. 11, 411-416.

9. D'Amore, T.; Stewart, G.G. (1987). Ethanol tolerance of yeast. Enzyme Microbial. Technol. 9, 322-330.

10. Dijck, P.V.; Colavizza. D.; Smet, P.; Thevelein, J.M. (1995) Differential importance of trehalose in stress resistance in fermenting and nonfermenting Saccharomyces cerevisiae cells. Appl. Environ. Microbiol. $6(1), 109-115$.

11. Ezeogu, L.I.; Okolo, B.N. (1994). Effect of molasses concentration and medium supplementation on the adaptability of a high level ethanol tolerance palm -wine Saccharomyces isolate. Biotechnol. Lett. 16 (1), 95-100.

12. Gancedo, C.; Flores, C-L (2004). The importance of a functional trehalose biosynthetic pathway for the life of yeasts and fungi. FEMS Yeast Res. 4, 351359.

13. Gancedo, C.; Serrano, R. (1989). Energy yielding metabolism. In: Rose, A.H., Harrison, J.S. (eds). The yeasts Vol. 3. Harcourt Brace Jovanovich Publishers, London, p.205-259.

14. Guyot, S.; Ferret, E.; Gervais, P. (2005). Responses of Saccharomyces cerevisiae to thermal stress. Biotechnol. Bioeng. 92(4), 403-409.

15. Hallsworth, E.T. (1998). Ethanol - induced water stress in yeast. $J$. Ferment. Bioengineer. 85 (2), 125-137.

16. Hottiger, T.; Boller, T.; Wiemken, A. (1987). Rapid changes of heat and 
desiccation tolerance correlated with changes of trehalose content in Saccharomyces cerevisiae cells subjected to temperature shifts. Federation of European Biochemical Society. 220 (1), 113-115.

17. Jones, R.P.; Greenfield, P.F. (1987). Ethanol and the fluidity of the yeast plasma membrane. Yeast. 3, 223-232.

18. Lee, Y-R.J.; Nagao, R.T.; Key, J.L. (1994). A soybean 101-kD heat shock protein complements a yeast HSP104 deletion mutant in acquiring thermotolerance. The Plant Cell. 6(12), 1889-1897.

19. Liu, H.J.; Liu, D.H.; Zhong, J.J. (2005). Interesting physiological response of the osmophilic yeast Candida Krusei to heat shock. Enzyme Microbial. Technol. 36 (4), 409-416.

20. Mansure, J.J.; Souza, R.C.; Panek, A.D. (1997). Trehalose metabolism in Saccharomyces cerevisiae during alcoholic fermentation. Biotechnol. Lett. 19 (12), 1201 - 1203.

21. Mansure, J.J.C.; Panek, A.D.; Crowe, L.M.; Crowe, J.H. (1994). Trehalose inhibits ethanol effects on intact yeast cells and liposomes. Biochemica Biophysica Acta. 1191, 309-316.

22. Maranon, I.M.; Chaudanson, N.; Joly, N.; Gervais, P. (1999). Slow heat rate increases in yeast thermotolerance by maintaining plasma membrane integrity. Biotechnol. Bioeng. 65(2), 176-181.

23. McAlister, L.; Finkelstein, D.B. (1980). Heat shock proteins and thermal resistance in yeast. Biochem. Biophys. Res. Commun. 93(3), 819-824.

24. Miller G.L. (1959). Use of dinitrosalicylic acid reagent for determination of reducing sugar. Anal. Chem. 81, 426-428.

25. Odemeru, J,D.; Amore, T.; Russel, I.; Steward, G.G. (1993). Alterations in fatty acid composition and trehalose concentration of Saccharomyces brewing strains in response to heat and ethanol shock. J. Ind. Microbiol. 11, 113-199.

26. Ogawa, Y.; Nitta, A.; Uchiyama, H.; Imamura, T.; Shimoi, H.; Ito, K. (2000). Tolerance mechanism of the ethanol-tolerant mutant of sake yeast. J. Bioscience and Bioengineering. 90(3), 313-320.

27. Parsell, D.A.; Taulien, J.; Lindquist, S. (1993). The role of heat-shock proteins in thermotolerance. J. Biol. Sc. 339(1289), 279-286.

28. Peres, M.F.S.; Laluce, C. (1998). Ethanol tolerance of thermotolerant yeasts cultivated on mixtures of sucrose and ethanol. J. Ferment. Bioengineer. 85(4), 388-397.

29. Piper, P.W. (1993). Molecular events associated with acquisition of heat tolerance by the Saccharomyces cerevisiae. FEMS Microbiol. Rev. 11, 339-356.

30. Ribeiro, M.J.S.; Reinders, A.; Boller, T.; Wiemken, A.; Virgilio, C.D. (1997). Trehalose synthesis is important for the acquisition of termotolerance in Schizosaccharomyces pombe. Mol. Microbiol. 25(3), 571-581.
31. Riberio, M.J.S., Leao, L.S.C., Morais, P.B., Rosa, C.A. and Panek, A.D. (1999). Trehalose accumulation by tropical yeast strains submitted to stress conditions. Antonie van Leeuwenhoek. 75, 245-251.

32. Sami, M.; Ikeda, M.; Yabuuchi, S. (1994). Evaluation of the alkaline methylene blue staining method for yeast activity determination. $J$. Ferment. Bioengineer. 78(3), 212 - 216.

33. Sharma, S.C. (1997). A possible role of trehalose in osmotolerance and ethanol tolerance in Saccharomyces cerevisiae. FEMS Microbiol. Lett. 152, 11-15.

34. Simola, M.; Hanninen, A.L.; Stranius, A-M.; Makarow, M. (2000). Trehalose is required for conformational repair of heat-denatured proteins in the yeast endoplasmic reticulum but for maintenance of membrane traffic functions after severe heat stress. Mol. Microbiol. 37(1), 42-53.

35. Singer, M.A.; Lindquist, S. (1998). Thermotolerance in Saccharomyces cerevisiae: the Yin and Yang of trehalose. Trends Biotechnol. 16, 460468.

36. Smith, B.J.; Yaffe, M.P. (1991). Uncoupling thermotolerance from the induction of heat shock proteins. Proc. Natl. Acad. Sci., USA. 88(24), 11091-11094.

37. Spiro, R.G. (1966). Analysis of sugars found in glycoprotein. Complex carbohydrates. In: Neufeld, E.F.; Ginsburg, V (Eds). Methods in Enzymology. Vol. 8 Academic Press, New York. p. 3-5.

38. Thermotolerance and trehalose accumulation induced by heat shock in yeast cells of Candida albicans. FEMS Microbiol. Lett. 146:65-71.

39. Trevalelyan, W.E.; Harrison, J.S. (1956). The trehalose content of Baker's yeast during anaerobic fermentation. Biochem. J. 62, 177-182.

40. Varly, H.A.; Gowenlocki, H.; Bell, M. (1980). Practical Clinical Biochemistry. Vol. 2, $5^{\text {th }}$ Edn. William Heiemann Medical Books Ltd, London. p. $312-313$.

41. Virgilio, C.D.; Piper, P.; Boller, T.; Wiemken, A. (1991). Acquisition of thermotolerance in Saccharomyces cerevisiae without heat shock protein hsp 104 and in the presence of protein synthesis. FEBS Lett. 288(1, 2), $86-90$.

42. Virgilio, C.D.; Simmen, U.; Hottiger, T.; Boller, T.; Wiemken, A. (1990). Heat shock induces enzymes of trehalose metabolism, trehalose accumulation and thermotolerance in Schizosaccharomyces pombe, even in the presence of cycloheximide. FEBS Lett. 273(1, 2), 107-110.

43. Walton, E.F.; Pringle, J.R. (1980). Effect of growth temperature upon heat sensitivity in Saccharomyces cerevisiae. Arch. Microbiol. 124, 285287.

44. Watson. K. (1987). Temperature relations. The Yeasts, Vol. 3. Rose, A.H.; Harrision, J.S. (eds). Harcout Brace Jovanovich Publishers, London. p. 41-71. 